\title{
An Assessment of Montaigne's Marital Relationship
}

\author{
Paul Venesoen \\ (Brescia College, University of Western Ontario, London)
}

On August 18, 1563, Etienne de La Boétie died at Germignan, near the city of Bordeaux. He was thirty-three years old and had possibly been Montaigne's only close friend. The memory of La Boétie would always haunt Montaigne's thought and emotions, for it is La Boétie who inspires the most beautiful pages written by Montaigne on friendship, more moving and sincere in tone than anything he ever wrote about love and women.

The loss of La Boétie left Montaigne, then thirty years old, confused and disturbed by a sense of desperation. Until that time, the idea of marriage never seemed to have crossed his mind, nor did such an idea even appear to have any usefulness. Two years later, nevertheless, on September 23, 1565, Montaigne married Françoise de Lachassaigne, the daughter of a member of the Parlement de Bordeaux. Obviously Montaigne had restricted the social environment of his future spouse to the fairly small world of honorable magistrates. As one critic puts it: "Entre cette famille et celle de Montaigne il y avait déjà des liens".' Françoise belonged to a desirable milieu and the class-oriented circumstances surrounding Montaigne's marriage may easily suggest that this marriage was one of convenience and a social match: both bride and groom were well off. ${ }^{2}$ One may even wonder if Montaigne did not try to find some consolation in his marriage to Françoise after La Boétie's death. When he speaks about his indolent decision to marry he does so in a very disenchanted tone. Had he listened to Socrates, he would have remained a bachelor, for "Socrate, enquis qui estoit plus commode prendre ou ne prendre point de femme : 'Lequel des deux on face, dit-il, on s'en repentira' ". ${ }^{3}$ He nevertheless gave in:

De mon dessein, $j$ 'eusse fuy d'espouser la sagesse mesme, si elle m'eust voulu. Mais, nous avons beau dire, la coustume et l'usage de la vie commune nous emporte. La plus part de mes actions se conduisent par exemple, non par chois. Toutefois je ne m'y conviay pas proprement, on m'y mena, et y fus porté par des occasions estrangeres. ${ }^{4}$

We do not detect much enthusiasm, but rather a mild willingness to do the proper thing. Montaigne admits he is part of a "marché", which does not 
It should be remembered that Montaigne undertook his Essais around the year 1572, maybe a little earlier, according to Maurice Rat's "Chronologie de Montaigne". The Livre III, however, full of observation on marriage in general, and on his own marital experience, is dated 1586-87. At that time Montaigne was fifty-five years old and had been married for twenty-two years. We are now listening to a man who has lost his youthful outlook on life, who is no longer in his "prime", and whose possible illusions about married life may have been slightly tarnished over the years. Without contesting the validity of his marital reflections in the Essais, one should put them in their proper chronological, and thus psychological, context.

Of perhaps more significant value is the dedicatory letter to his wife, written as an introduction to La Boétie's translation of the "Lettre de consolation de Plutarque à sa femme", which Montaigne submits to Françoise, who has just lost her first child. There is a touching element in this letter, for Montaigne links Françoise's sorrow to the memory of his dear friend La Boétie. It is as if friend and wife have been united within the warm and loving feelings of Montaigne. Montaigne's tone is tender, yet embarrassed, for he still remains a typical sixteenth-century husband:

Ma Femme vous entendez bien que ce n'est pas le tour d'un galand homme, aux reigles de ce temps icy, de vous courtiser $\&$ caresser encore. Car ils disent qu' un habil homme peut bien prendre femme: mais que de l'espouser c'est à faire à un sot. Laissons les dire: je me tiens de ma part à la simple façon du vieil age, aussi en porte-je tantost le poil. ${ }^{5}$

Here we listen to the language of an affectionate husband who blushes over his own sensitivity, so contrary to the expected emotional attitudes of the men of his time. And he adds: "Vivons ma femme, vous \& moy, à la vieille Françoise", which is clearly a compliment addressed to their marital harmony and to the feelings of love and tender friendship between them.

Not every critic has been kind towards the implications of this dedicatory letter. It has been suggested that Montaigne insists more on his wife's duties than on his sympathy for her, even if he signs "Vostre bon mary". One has been disappointed by a Montaigne who apparently asks Plutarch to console his wife instead of relying on his own good words: "witnessing his wife's sorrow, Montaigne left to Plutarch the duty of consoling her. His letter to her is less a loving dedication than a reminder of her duties". ${ }^{6}$ Such a critical view, however, does not take into account the almost natural reflex of an intellectual and, moreover, of a man of the sixteenth century, who fears ridicule for being too sensitive, and prefers to hide his true feelings behind a balance of rational 
thought and emotional restraint. The persistence in the sixteenth century of the "querelle des femmes" imposes a fashionable misogyny on most men, or at least an air of detachment which has become part of virile discourse and social behaviour.

On the other hand, what do we now about Françoise's feelings towards her husband? Supporting documents are scarce. When Montaigne dies, on September 13, 1592, Madame de Montaigne "fit porter son corps a Bordeaus et le fit enterrer an l'eglise de Foeuilles ou elle luy fit faire un tombeau eslevé et acheta pour cela la fondation de lesglise. ${ }^{17}$ It may be argued that her behaviour was most traditional, but there was certainly no lack of respect. Furthermore, a year and a half after the death of her husband, Françoise copies her husband's Essais with the help of Pierre de Brach, and asks Marie de Gournay, Montaigne's "fille d'alliance", to handle the publication. Françoise's initiative is therefore not only a tribute to her husband and his writings, but also a most thoughtful recognition of his amiability towards others.

Correspondence between Françoise de Lachassaigne and the Révérend P. Marc-Antoine de Saint-Bernard has also led to some speculation about the husband-wife relationship. One reads here that Françoise "conserva pieusement le souvenir du mari, de qui elle tenait 'tout le bien' qu'elle avait". ${ }^{8}$ Such positive feelings about Montaigne's relationship with his wife have been expressed several times without overly romantic expectations.

A stout defender of marital harmony is Paul Bonnefon. In his Montaigne et ses amis, ${ }^{9}$ he has nothing but praise for Françoise:

C'était une femme de grand sens. Elle sut bien vite, sans jamais s'imposer, faire sentir autour d'elle une influence bienfaisante. Elle fut une compagne discrète et dévouée, telle que Montaigne l'avait rêvée. ${ }^{10}$

Bonnefon points out that Montaigne did not seek love (which cannot be defined in nineteenth- or twentieth-century terms) in marriage, but rather a solid friendship, and that Françoise was totally in agreement with such a practical and reassuring idea of a lasting relationship between husband and wife. Bonnefon's statements, however, seem more personal than factual. He concedes that Montaigne "ne nous a rien dévoilé de son bonheur domestique", but this simply means "qu'il faudrait voir dans ce silence un délicat hommage au charme de la vie intérieure", and that basically, Françoise was the ideal wife "dans la pénombre de la gloire de [son] mari"." Bonnefon's views may well reflect nineteenth-century French impressions, or Victorian opinions about married life for that matter, instead of the actual reality of Montaigne's marital experience. Bonnefon's rather phallocratic views have been shared by Paul Stapfer, ${ }^{12}$ and to 
a certain extent by Jean Plattard in his Montaigne et son temps. Stapfer is well aware of the critical assessment of Montaigne's marriage, but he remains convinced that all in all the Montaigne ménage was a happy one: "Ce qui est beaucoup plus digne de remarque, c'est l'insignifiance même de ces vagues et rares confidences et l'impression que les Essais nous laissent en somme d'une femme estimée et d'un mariage heureux". ${ }^{13}$ As for Plattard, he relies on Montaigne's faithfulness, which should obviously demonstrate a harmonious marital relationship: "Cette fidélité est assez exceptionnelle alors pour mériter d'être mentionée". ${ }^{14}$ Faithfulness is exceptional because it is more often found among les "marchands et [les] bourgeois", a widespread opinion confirmed by Montaigne himself when he talks about marriage in the Essais:

Il faut la rencontre de beaucoup de qualitez à le bastir. Il se trouve en ce temps plus commode aux ames simples et populaires, où les delices, la curiosité et l'oysiveté ne le troublent pas tant. ${ }^{15}$

Plattard goes on to state that Montaigne does not easily submit to public opinion, for the image of Françoise which emerges from the Essais is sufficient proof of Montaigne's affection for his wife. Unfortunately, as for almost everything else in Montaigne's Essais, such an image may appear to be very positive but also very negative, according to the various excerpts one chooses. It is quite possible that Montaigne occasionally thought about his wife when he wrote about women, love or friendship. His intellectual mind, however, was sufficiently autonomous to allow him to reflect more objectively upon womanhood and its relationship to manhood, without having to refer to the ups and downs of his own marriage. Plattard relies too heavily on constant interference of biographical elements in the creative process of the Essais, which makes him say that: "Tout semble indiquer que le ménage de Montaigne est à ranger dans la catégorie, qu'il dit nombreuse, des bons ménages". ${ }^{16}$ A kind speculation, nothing more.

A degree of optimism and confidence has not been shared by all critics. There are reservations, and at times even some cynicism. Already in a study which goes back to $1860, \mathrm{~F}$. Bigorie de Laschamps boldly writes: "Montaigne $s^{\prime}$ ennuie dans son ménage, et $s^{\prime} y$ trouve plus mal de jour en jour". ${ }^{17}$ The critic implies ennui, indifference and even a degree of hostility towards Françoise de Lachassaigne. But it is Paul Laumonier's detailed analysis in his "Madame de Montaigne, d'après les Essais," which launches the most concerted attack against the "tableau tout idyllique" which had emerged from the Plattard, Bonnefon and Stapfer studies. According to Laumonier, textual analysis rules out any heartwarming picture of Montaigne's ménage. He discards the positive 
significance of the dedicatory letter of 1570 , for it dates "seulement de la cinquième année de leur mariage, et [Montaigne"] n'avait pas encore eu le temps de s'ennuyer dans son manoir périgourdin ni de se blaser dans son ménage". ${ }^{18}$ In other words, boredom and resentment take more than five years to develop. Laumonier's bias is perhaps as strong as Plattard's. He nevertheless keeps on reaching for more convincing arguments, using extensive quotations from the "De l'affection des pères aux enfants" (II, VIII) or from "De la colère" (II, XXXI), where "c'est bien à sa femme que [Montaigne] adressait indirectement ce double avertissement, car quels autres que sa femme et lui avaient le droit de se courroucer en sa famille et en son logis?"19 It seems that this statement by Laumonier is based on a misunderstanding of Montaigne's remarks about colère. Montaigne talks quite objectively about anger, especially when it is directed against servants for petty reasons. He also mentions femmes testues but nothing points to Françoise. As for the avertissement, it is obviously meant for himself and possibly for Françoise when they have to deal with their servants. One could even imagine that these occurrences can hardly be called "une querelle de ménage".

In chapter XXXII (Livre II), Laumonier reads about Montaigne's displeasure at the stubbornness of women and swiftly concludes that Françoise is the target. Montaigne writes:

J'ay cogneu cent et cent femmes, car ils disent que les testes de Gascongne ont quelque prerogative en cela, qeu vous eussiez plustost faict mordre dans le fer chaut que de leur faire desmordre une opinion qu'elles eussent conçeue en cholere. ${ }^{20}$

But Françoise is from the Bordeaux region: she is a daughter of Guyenne, not of Gascogne. Obviously Laumonier doesn't take such geographical details into account, and we must assume that he hasn't heard about regional labels. They belong to popular, and sometimes quite erroneous, history. If Montaigne is guilty, it is not of scolding his wife, but of repeating some harmless common belief.

Finally, Laumonier finds ground for an unhappy marriage in "Sur des vers de Virgile" (III, V), in the "Art de conférer" (III, VIII) and in "De la vanité" (III, IX). What the critic actually finds are various observations about love and about marriage in general, two topics Montaigne would touch upon whether he was married or not, or whether he was ever "in love" or not. It is not because Montaigne claims in his "Au Lecteur" that "c'est moy que je peins", that everything in the Essais has to be looked upon as being an account of his everyday experiences. What he means is that the reader can discover the way he thinks and reacts without lying about himself or without hiding behind vain 
excuses. Furthermore, the Essais are also the work of an accomplished érudit, constantly referring to the opinions of the classical writers of Greece or Rome. Set against their background, the Essais come through as a dialectical and mostly intellectual exercise, striving for objectivity and personal detachment. Only the memory of La Boétie succeeds in revealing some of Montaigne's deep personal feelings. On the other hand, marriage and love are wittily discussed without Françoise's help or interference.

A less emotionally involved study dealing with Montaigne's biography and his marital relationship is Donald M. Frame's work, Montaigne A Biography. ${ }^{21}$ Donald Frame reminds us of Maurice Rat and Alexandre Nicolai's fierce determination to accuse Françoise of adultery, ${ }^{22}$ which would be a truly sensational story with Montaigne as a cuckold husband, and the seducer being no other than Montaigne's own brother, Arnaud! But as Frame justly points out: this account rests on few facts. We know little of young Françoise's beauty, nothing of her lustiness. ${ }^{23}$ Frame then proceeds very cautiously in examining some passages from the Essais, which could lead to a few hypotheses on the couple's relationship. Montaigne has complained about Françoise's lack of thriftiness; he did not hold her role as educator of the children in great esteem. But were they fighting over it? Were those minor differences grounds for hostility or a limping marriage? Nothing frightening transpires from the Essais, and when Montaigne speaks about marriage, he does so with a definite degree of approval:

C'est une douce société de vie, pleine de constance, de fiance et d'un nombre infiny d'utiles et solides offices et obligations mutuelles. [...] A le bien façonner et à le bien prendre, il n'est point de plus belle piece en nostre société. Nous ne nous en pouvons passer, et l'allons avilissant. ${ }^{24}$

These are not the words of a man who feels miserable in his marital relationship. He is not saying that everything in marriage is perfect bliss, and once again Socrates is on his side. But having put everything into perspective, he has probably come to the conclusion that marriage is "a mixture of satisfaction and frustration, better than he had expected, but one in which the roses were outnumbered by the thorns". ${ }^{25}$

In fact, in Montaigne's mind, marriage is simply a "relationship", irreplaceable and necessary in order to maintain society's coherent structure. Montaigne's view was realistic, cool, and unromantic, but also totally unacceptable to the likes of Louise Labé, Nicole Liébault, ${ }^{26}$ or Marguerite de Navarre. Montaigne never links love to the idea of marriage, for love is a basic physical pleasure, ${ }^{27}$ unrelated to the idea of two people sharing their lives, their 
Montaigne's view was realistic, cool, and unromantic, but also totally unacceptable to the likes of Louise Labé, Nicole Liébault, ${ }^{26}$ or Marguerite de Navarre. Montaigne never links love to the idea of marriage, for love is a basic physical pleasure, ${ }^{27}$ unrelated to the idea of two people sharing their lives, their hopes and their sorrows. Montaigne's marriage (and his idea of marriage) is a partnership with each partner playing his and her traditional role. It is true that Montaigne sounds slightly male chauvinistic according to today's feminine or feminist criteria. But one can hardly expect a sixteenth-century seigneur to consider his marital relationship from the point of view of total equality between husband and wife. Anyone would be hard-pressed to find genuine disrespect on Montaigne's part for Françoise, his wife of twenty-seven years. In fact, it appears to be slightly anachronistic to label Montaigne's attitude towards women and towards his wife and daughter Leonor as "indulgent contempt", an accusation made by Cecile Insdorf, and shared by Edith Sichel who writes that "his personal life is characterized by a more selfish and condescending attitude towards his wife". ${ }^{28}$ To brand Montaigne with a twentiety-century iron is not really too convincing. Auguste Bailly, in his Montaigne $e^{29}$ is less disturbed. He simply acknowledges the undeniable fact that Montaigne was a man of his times, coping with his marital relationship with probably more intelligence than most other men, but never, states Bailly, Montaigne "ne considéra sa femme comme une égale : ni les habitudes du temps, ni son imitation passionnée des vieux Romains, ne pouvaient lui inspirer le goût d'une intimité profonde." ${ }^{30}$

Any assessment of Montaigne's marital relationship cannot avoid dealing with the emotions of his numerous critics, either well-disposed or ill-disposed. Indifference to Montaigne's writings is impossible, and impassivity towards the Essais has become an unbearable challenge--to like Montaigne is either to side with him or to regret his alleged mistakes. We have seen that critics usually take extreme and opposing points of view. No one is willing to admit that Montaigne did not feel like telling us much about his own marriage. He thought perhaps that it was not important enough to be discussed, or that his marriage was nobody's business but his own. Since Montaigne's life does not seem to have been marred by a serious crisis or any identifiable tragedy (except for La Boétie's death), one may cautiously conclude that his marriage was simply an uninspired, unexciting, uneventful, dull and, at times, boring experience. Neither paradise nor hell, his marriage was a gentle purgatory fit for a man whose wisdom steered him through life. 


\section{NOTES}

1 Jean Plattard, Montaigne et son temps (Genève: Slatkine Reprints, 1972), p. 96.

2 Françoise's dowry was estimated at 7000 livres, "belle somme, puisqu'elle équivaudrait en 1933 à environ un million cinq cent mille francs-papier" (J. Plattard, op. cit.). Montaigne himself received a quarter of the income of the domain of Montaigne.

3 Montaigne, Oeuvres complètes, Bibliothèque de la Pléïade (Paris: Gallimard, 1962), III, V, p. 829. From here on referred to as O.C.

4 O.C., III, V, 830.

5

O.C. "A Mademoiselle de Montaigne", p. 1371.

6 Cecile Insdorf, Montaigne and Feminism (Chapel Hill: North Carolina Studies in the Romance Languages and Literatures, 1977), p. 56.

7 See Notes relatives à la naissance et à la mort de Montaigne, in O.C., p. 1415 .

8 Paul Laumonier, "Madame de Montaigne d'après les Essais", in Mélanges offerts à M. Abel LeFranc (Paris: E. Droz, 1936), p. 394 . For the correspondence of Françoise at the age of seventy, we refer to the commentaries of Donald M. Frame, Montaigne A Biography (New York: Harcourt, Brace \& World, Inc., 1965) pp. 87-89.

9 Published in Paris in 1898, reprinted by Slatkine in 1969.

10 op. cit., I. p. 87 .

11 op. cit., pp. 87-88.

12 Paul Stapfer, Montaigne (Paris: Hachette, 2e éd., 1913). 
Op. cit., p. 35.

14 op. cit., p. 99.

15 O.C., III, V, p. 829.

16 op. cit., p. 102 .

17 Bigorie de Laschamps, Michel de Montaigne (Paris: Firmin Didot frères, 1860), p. 29.

18

Op. cit., p. 396.

19 op. cit., p. 399.

20 O.C., II, XXXII, pp. 702-703.

21 op. cit.

22 Maurice Rat, "Le Ménage de Montaigne", in Bulletin de la Société des amis de Montaigne, II, 15, (1949-52), pp. 14-23, \& II, 18 (Jan.-Juin, 1956), pp. 26-27. Alexandre Nicolaï, Montaigne intime (Paris: Aubier, Editions Montaigne, s.d.).

23 op. cit., p. 90.

24

O.C., III, V, p. 829.

25 Donald Frame, op. cit., pp. 101-102.

${ }^{26}$ Her Les Misères de la femme mariée, published with some commentaries by Ilana Zinguer (Genève: Editions Slatkine, 1982), belong to the neo-platonic writings of the sixteenth century, strictly along the lines of Marguerite de Navarre's naïve feminism.

27 The most comprehensive article, to our knowledge, on Montaigne's idea of love being essentially defined by physical pleasure is written by Michel 
Dassonville, "Le Coeur de Montaigne", Bibliothèque d'Humanisme et Renaissance, XXV, 1963.

28 Cecile Insdorf, op. cit., p. 53, quotes Edith Sichel in her Michel de Montaigne (London: Constable \& Co., Ltd., 1911).

29 Auguste Bailly, Montaigne (Paris: Arthème Fayard, 1942).

30 op. cit. p. 118.

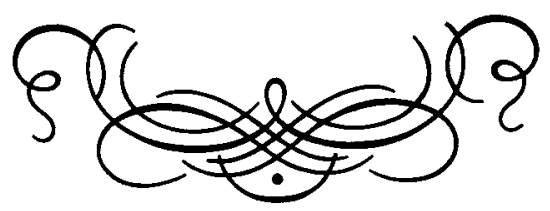

